\title{
Unusual cause for small bowel obstruction
}

\author{
Zheng Andrew Zhang, ${ }^{1}$ David Lan Cheong Wah, ${ }^{2}$ Thair M Abbas Al-Dujaili ${ }^{2}$
}

${ }^{1}$ General Surgery, Royal Melbourne Hospital, Melbourne, Victoria, Australia

${ }^{2}$ General Surgery, Goulburn Valley Health, Shepparton, Victoria, Australia

Correspondence to Dr Zheng Andrew Zhang, andrew.zhang@mh.org.au

Accepted 29 August 2018
D) Check for updates

(c) BMJ Publishing Group Limited 2018. No commercial re-use. See rights and permissions. Published by BMJ.

\begin{tabular}{|l|}
\hline To cite: Zhang ZA, \\
Lan Cheong Wah D, \\
Al-Dujaili TMA. BMJ Case \\
Rep Published Online First: \\
[please include Day Month \\
Year]. doi:10.1136/bcr-2018- \\
227308 \\
\hline
\end{tabular}

\section{DESCRIPTION}

Foreign body ingestion is a common occurrence. Although over $80 \%$ of ingestions resolve spontaneously, approximately $1 \%$ of cases will require open surgical intervention. We present a rare case of foreign body ingestion in an 18-year-old man causing distal mechanical small bowel obstruction, requiring exploratory laparotomy and enterotomy.

An 18-year-old man with no significant medical history and no previous abdominal operations presented to a regional hospital with a 5-day history of persistent nausea, vomiting, absolute constipation and generalised abdominal pain. On clinical examination, he was tachycardic (116 beats/ min) with a low-grade temperature $\left(37.8^{\circ} \mathrm{C}\right)$, and had abdominal distension with central abdominal guarding. Plain films showed dilated loops of small bowel, consistent with small bowel obstruction. White cell count was $7.5 \times 10^{9} / \mathrm{L}$ and $\mathrm{C}$ reactive protein was $74 \mathrm{mg} / \mathrm{L}$.

Subsequent evaluation with a CT scan demonstrated appearance of small bowel obstruction with at least one transition point in the left lower abdomen, with features concerning for internal herniation or mesenteric torsion resulting in closed loop obstruction. No foreign objects were seen at the initial reporting of imaging. A nasogastric tube was placed and an emergency explorative laparotomy was performed for concerns of closed loop bowel obstruction. Intraoperatively, small bowel dilatation was found throughout, up to the distal ileum. A soft, fluctuant and intraluminally mobile mass of approximately $4 \mathrm{~cm}$ in length was palpated in the distal ileum (figure 1). The mass was causing

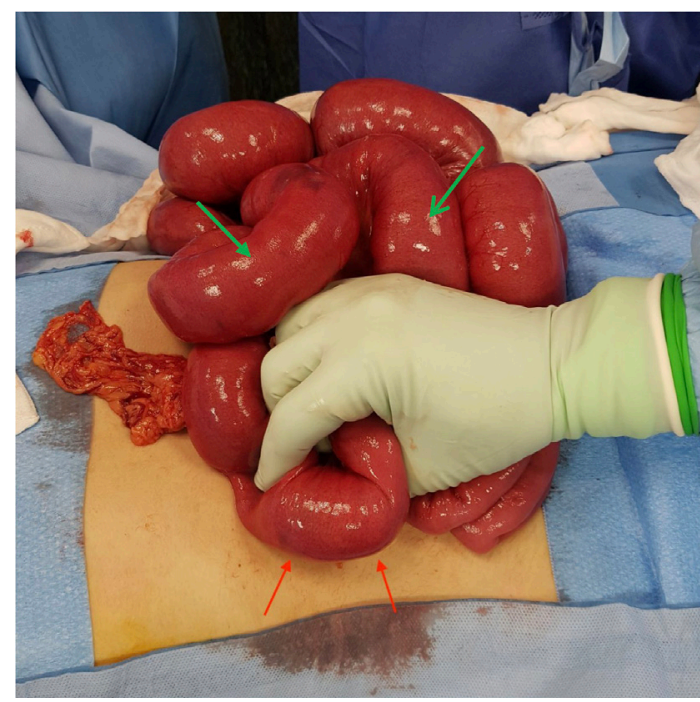

Figure 1 Intraoperative photo showing small bowel dilatation (green arrow) and soft fluctuant mass in the terminal ileum (red arrow).

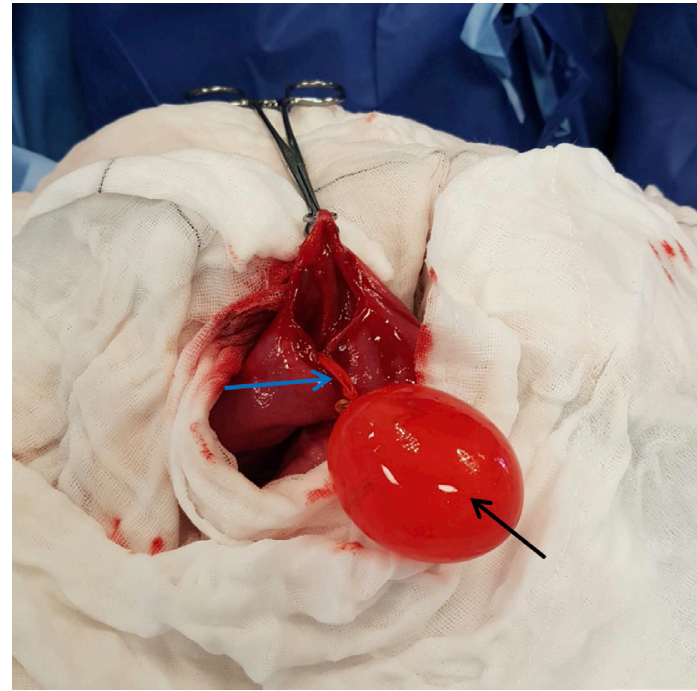

Figure 2 Intraoperative photo showing water-filled rubber balloon (black arrow) and the tail of the balloon with a string attached (blue arrow).

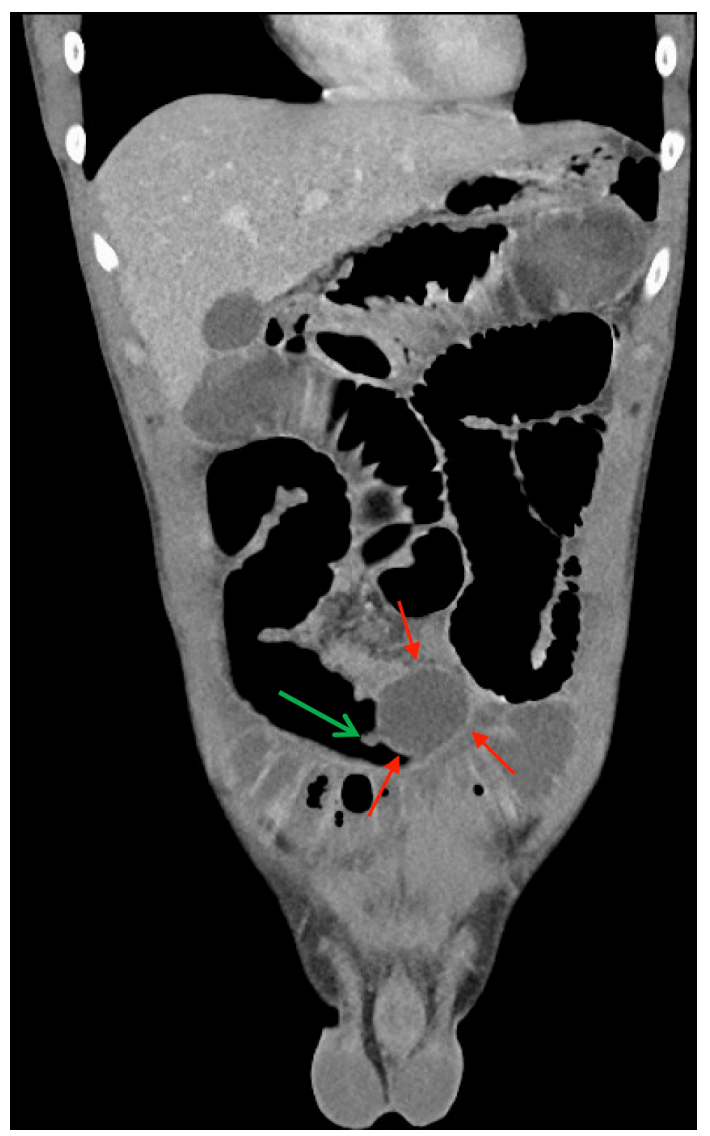

Figure 3 Coronal CT scan of the abdomen showing a radiolucent balloon in the distal ileum (red arrow) with balloon tail (green arrow). 
severe obstruction, and the bowel distal to this was collapsed. Enterotomy revealed a water-filled rubber balloon (figure 2). No history of foreign body ingestion was given by the patient on repeat assessments postoperatively. Given the density of the water balloon, only on retrospective review of the initial CT imaging was the foreign body identified (figure 3 ). The patient was discharged home after tolerating enteral nutrition and outpatient psychiatry review organised.

Foreign body ingestion occurs primarily in young children between the ages of 6 months and 3 years, although ingestions can also present in other settings such as intentional ingestion in psychiatric patients or prison inmates.

The diagnosis of foreign body ingestion is primarily made clinically, although a history of foreign body ingestion may not always be available. Radiopaque objects can be localised

\section{Learning points}

- Foreign body ingestion is a common occurrence, and although few cases require open surgical intervention, urgent surgical removal is indicated in certain situations such as bowel obstruction/inflammation.

- A high index of suspicion is required as the diagnosis is primarily made clinically.

- Radiolucent objects may not be localised on radiographic investigations and a reliable history is not always available.

- Complications of foreign body ingestion include ulcer formation, mucosal laceration, perforation, intestinal obstruction, fistula formation and bacteraemia. and identified via biplanar radiographs, but radiolucent ones can evade timely diagnosis if a clinical history is lacking. Distal obstruction occurs in less than $10 \%$ of cases, where the most common point of impaction is the ileocaecal valve. Complications of foreign body ingestion include ulcer formation, mucosal laceration, perforation, intestinal obstruction, fistula formation and bacteraemia. ${ }^{1}$

Urgent intervention to remove a foreign body is indicated in certain situations such as airway compromise, oesophageal obstruction, signs and symptoms of intestinal inflammation or obstruction, or if the foreign object is sharp, long, consists of magnets, superabsorbent polymer or batteries. Over $80 \%$ of ingestions resolve spontaneously and pass without a need for intervention. ${ }^{2}$ In $20 \%$ of cases, endoscopic intervention is indicated. Less than $1 \%$ of ingested foreign bodies require open surgical intervention. ${ }^{2}$

Contributors ZAZ: writing of paper. DLCW: study design. TMAA: supervision and editing.

Funding The authors have not declared a specific grant for this research from any funding agency in the public, commercial or not-for-profit sectors.

Competing interests None declared.

Patient consent Obtained.

Provenance and peer review Not commissioned; externally peer reviewed.

\section{REFERENCES}

1 Jayachandra S, Eslick GD. A systematic review of paediatric foreign body ingestion: presentation, complications, and management. Int J Pediatr Otorhinolaryngol 2013:77:311-7.

2 Ambe P, Weber SA, Schauer M, et al. Swallowed foreign bodies in adults. Dtsch Arztebl Int 2012;109:869-75.

Copyright 2018 BMJ Publishing Group. All rights reserved. For permission to reuse any of this content visit http://group.bmj.com/group/rights-licensing/permissions.

BMJ Case Report Fellows may re-use this article for personal use and teaching without any further permission.

Become a Fellow of BMJ Case Reports today and you can:

- Submit as many cases as you like

- Enjoy fast sympathetic peer review and rapid publication of accepted articles

- Access all the published articles

- Re-use any of the published material for personal use and teaching without further permission

For information on Institutional Fellowships contact consortiasales@bmjgroup.com

Visit casereports.bmj.com for more articles like this and to become a Fellow 